\title{
VẤN ĐỀ CON NGƯờI TRONG LICCH SỬ TU' TƯỞNG VIÊT NAM (TƯ THỜI KỲ DỰNG NƯỚC ĐẾN ĐẦU THẾ KỶ XX)
}

\author{
NGUYỄN TRUNG DŨNG \\ Khoa Lý luận Chính trị,Truờng Đại học Công nghiệp Thành phố Hồ Chí Minh \\ ntdunghui@gmail.com
}

Tóm tắt: Bài viết nghiên cứu vấn đề con người trên phương diện triết học, hệ thống hóa quan niệm, quan điểm của các nhà tư tưởng trong lịch sử Việt Nam (từ thời kỳ dựng nước đến đầu thế kỷ XX) về nguồn gốc, bản tính, vị trí và vai trò của con người, ý thức về chủ quyền và lòng tự hào dân tộc, tư tưởng về đạo làm người. Đây là những vấn đề chủ yếu, xuyên suốt trong quá trình lịch sử phát triển tư tưởng của dân tộc, phản ánh đặc điểm cơ bản lịch sử vận động và xây dựng đất nước. Qua đó, giúp chúng ta hiểu hơn về những giá trị cốt lõi về con người Việt Nam truyền thống và ý nghĩa đối với việc xây dựng con người phát triển toàn diện, đáp ứng yêu cầu công nghiệp hóa, hiện đại hóa ở nước ta hiện nay.

Từ khóa. vấn đề con người, tư tưởng Việt Nam

\section{HUMAN AFFAIRS IN THE HISTORY OF VIETNAMESE THOUGHTS (FROM THE COUNTRY ESTABLISHMENT PERIOD TO THE BEGINNING OF 20TH CENTURY)}

Summary: the article studies philosophically human affairs, systematises conceptions, opinions of ideologists in the history of vietnamese thoughts (from the establishment period to the beginning of twentieth century) in terms of origin, nature, position and role of human, the sense of sovereignty and ethnic pride, thoughts about life point of view. These are major issues, throughout the course of the history of ethnic thought development, reflecting on the fundamental characteristics of historical movement and national development, thereby help us have a better understanding about the core values of traditional vietnamese people and significance towards the construction of fully developed citizens, and the satisfaction for the requirements of industrialization and modernisation of our country nowadays.

Keywords. Human affairs, vietnamese thoughts

\section{ĐĂT VẤN ĐỀ}

Hiện nay, toàn cầu hóa là xu thế tất yếu khách quan, lôi cuốn tất cả các quốc gia trên thế giới tham gia và tác động sâu rộng đến các lĩnh vực của đời sống kinh tế, xã hội, đến sự vận động và phát triển của mọi quốc gia, dân tộc. Việt Nam là quốc gia năng động, tham gia tích cực vào quá trình toàn cầu hóa, đang tận dụng được cơ hội to lớn do quá trình này mang lại nhằm thúc đẩy quá trình phát triển kinh tế, xã hội, không ngừng nâng cao đời sống vật chất và tinh thần cho Nhân dân. Tuy nhiên, bên cạnh những cơ hội do quá trình toàn cầu hóa mang lại, Việt Nam cũng đứng trước nhiều nguy cơ, thách thức đối với sự nghiệp đổi mới và xây dựng chủ nghĩa xã hội. Đại hội đại biểu toàn quốc lần thứ XII (năm 2016) vạch rõ: "Bốn nguy cơ mà Đảng ta đã chỉ ra vẫn tồn tại, nhất là nguy cơ tụt hậu xa hơn về kinh tế so với các nước trong khu vực và trên thế giới, nguy co "diễn biến hòa bình" của thế lực thù địch nhằm chống phá nước ta; tình trạng suy thoái về tư tưởng chính trị, đạo đức, lối sống, những biểu hiện "tự diễn biến", "tự chuyển hóa" trong một bộ phận cán bộ, đảng viên, công chức, viên chức; sự tồn tại và những diễn biến phức tạp của tệ quan liêu, tham nhũng, lãng phí..." [1, p. 19]. Chính vì vậy, Đảng và Nhà nước ta quan tâm đặc biệt đến con người, coi con người là trung tâm, mục tiêu, động lực của sự phát triển, định hướng sự nghiệp xây dựng con người xã hội chủ nghĩa Việt Nam phải gắn liền với xây dựng nhân cách phát triển hài hoà, kế thừa truyền thống và hiện đại, vừa "hồng" vừa "chuyên". Giá trị truyền thống có vai trò rất quan trọng đối với việc xây dựng và phát triển nhân cách con người Việt Nam trong bối cảnh toàn cầu hóa hiện nay trên nhiều phương diện, là "bộ lọc", "kháng thể" chống lại tác động tiêu cực của toàn cầu hóa và kịnh tế thị trường; góp phần xây dựng nhân cách mới, gắn lý tưởng, ước mơ hoài bão với hành động của con người hiện nay, nhất là thế hệ trẻ. Bối cảnh mới đang tạo ra cho Việt Nam cơ hội phát huy những giá trị truyền thống, tiếp thu có chọn lọc những giá trị tinh hoa của nhân loại trong xây dựng con người mới vì sự nghiệp đổi mới và 
phát triển. Nghiên cứu vấn đề con người trong lịch sử tư tưởng Việt Nam (từ thời kỳ dựng nước đến đầu thế kỷ $\mathrm{XX}$ ) không chỉ nhằm làm rõ hơn sự vận động và phát triển của tư tưởng Việt Nam, mà còn góp phần rút ra những đặc điểm, giá trị cốt lõi về con người truyền thống, qua đó rút ra được ý nghĩa đối với việc xây dựng con người trong giai đoạn hiện nay ở nước ta.

Tư tưởng Việt Nam nói chung, vấn đề về con người trong lịch sử tư tưởng Việt Nam nói riêng, trong quá trình hình thành, phát triển, đã phản ánh sâu sắc những điều kiện, đặc điểm về kinh tế, chính trị, văn hóa của đất nước. Mặc dù ở những thời kỳ lịch sử khác nhau, bối cảnh kinh tế - xã hội của đất nước có những biểu hiện khác nhau, nhưng nhìn chung, chúng ta có thể khái quát những đặc điểm cơ bản của lịch sử dân tộc trên ba vấn đề lớn:

Một là, dân tộc Việt Nam có sự hình thành quốc gia dân tộc khá sớm. Vào khoảng nửa đầu thiên niên kỷ thứ II trước Công nguyên, lịch sử dân tộc bước vào thời đại Hùng Vương với nhiều chuyển biến sâu sắc về kinh tế, chính trị, văn hóa. Đó là sự phát triển mạnh mẽ của nghề trồng lúa nước, nghề chăn nuôi, nghề gốm, nghề chế tác đá và nghề luyện kim loại đồng thau với dấu ấn của nền văn minh qua các giai đoạn Phùng Nguyên, Đồng Đậu, Gò Mun, Đông Sơn,... Sự phát triển của kinh tế nông nghiệp trồng lúa nước đòi hỏi người dân phải chung sức, chung lòng cùng tham gia công tác thủy lợi đào kênh mương tưới tiêu, mở mang diện tích canh tác và cùng nhau chống chọi với sức mạnh của tự nhiên để bảo vệ mùa màng, tài sản. Từ đó, ý thức có chung một cội nguồn, ý thức cộng đồng, ý thức chủ quyền quốc gia hình thành rất sớm. Sự ra đời của quốc gia và nhà nước Văn Lang - Âu Lạc là kết quả của quá trình chuyển biến về kinh tế, xã hội của thời Hùng Vương, đánh dấu một bước chuyển cơ bản trong lịch sử xã hội Việt Nam, mở ra một thời đại mới - thời đại dựng nước.

Hai là, trong suốt tiến trình lịch sử, dân tộc Việt Nam vừa dựng nước vừa đấu tranh chống các thế lực ngoại xâm hùng mạnh nhất trên thế giới. Từ thế kỷ thứ III trước Công nguyên, dân tộc ta đã đánh tan cuộc xâm lược đầu tiên của phong kiến phương Bắc do nhà Tần tiến hành. Từ năm 179 trước Công nguyên đến năm 905 , nước ta tiếp tục chịu sự đô hộ của phong kiến phương Bắc. Đây là thời kỳ lịch sử đầy máu và nước mắt, nhưng cũng là thời kỳ biểu hiện tinh thần quật cường, ý chí độc lập tự chủ của dân tộc ta. Trong thời kỳ Bắc thuộc, Nhân dân ta đã liên tục vùng dậy đấu tranh vũ trang để giành lại độc lập tự chủ, với các cuộc khởi nghĩa vang dội như cuộc khởi nghĩa của Hai Bà Trưng, Bà Triệu, Lý Bí, Mai Thúc Loan, Phùng Hưng v.v... và kết thúc hơn một nghìn năm Bắc thuộc bằng cuộc khởi nghĩa của Khúc Thừa Dụ năm 905 . Tiếp sau thời kỳ này là hàng loạt các chiến thắng vang dội khác như cuộc kháng chiến của Ngô Quyền năm 938 với chiến thắng Bạch Đằng oanh liệt, Lê Hoàn đánh tan quân Tống năm 981 , nhà Trần ba lần đánh bại quân Nguyên - Mông, Lê Lợi đánh bại quân Minh, Nguyễn Huệ đánh bại quân Thanh,... Rồi đến những thắng lợi vang dội của các cuộc kháng chiến chống Pháp, chống Mỹ trong thời kỳ lịch sử hiện đại. Trong những cuộc chiến tranh tàn khốc đó, nếu không có tinh thần yêu nước, lòng tự hào tự tôn dân tộc thì một dân tộc nhỏ yếu như chúng ta không thể làm nên những chiến trắng vang dội, đánh thắng được những kẻ thù mạnh nhất thế giới. Lòng yêu nước ở mỗi người dân Việt Nam đã được thể hiện ở tinh thần dám xả thân vì nước, sẵn sàng đặt lợi ích của quốc gia, dân tộc lên trên lợi ích riêng tư của mình, đấu tranh không biết mệt mỏi cho sự nghiệp giải phóng đất nước, giành lại độc lập tự do cho Tổ quốc.

Ba là, nước ta nằm ở vị trí địa lý thuận lợi của vùng Đông Nam Á, nằm trên các đầu mối giao thông thủy bộ quan trọng từ Bắc xuống Nam, từ Đông sang Tây. Chính vì vậy, Việt Nam thuận lợi trong việc giao lưu về kinh tế, văn hóa với các nước. Trong quá trình phát triển nói chung, văn hóa dân tộc đã tiếp nhận sự ảnh hưởng của các nền văn hóa khác nhau như văn hóa Trung Quốc, Nhật Bản, phương Tây v.v... Do vậy, các hệ thống tư tưởng về con người và giải phóng con người trong lịch sử tư tưởng Việt Nam đã tiếp thu, kế thừa và phát triển các dòng tư tưởng khác nhau của cả phương Đông và phương Tây, mà đặc biệt là quan điểm về con người và giải phóng con người trong chủ nghĩa Mác-Lênin.

Tư tưởng Việt Nam nói chung, tư tưởng về con người nói riêng trong lịch sử phản ánh sâu sắc những đặc điểm cơ bản của lịch sử phát triển dân tộc. Thực chất vấn đề con người trong lịch sử tư tưởng là quyền con người, giải phóng con người, giải phóng dân tộc, khẳng định vị trí, vai trò, thái độ của con người trước vận mệnh dân tộc. Có thể khái quát vấn đề con người trong lịch sử tư tưởng Việt Nam với các nội dung cơ bản sau đây:

\section{Tư tưởng về nguồn gốc và bản tính con người}

Trải qua hàng ngàn năm, nền kinh tế Việt Nam thực chất là nền kinh tế tiểu nông, lạc hậu, dựa trên sản xuất nông nghiệp theo lối độc canh cây lúa là chủ yếu, thủ công nghiệp, thương nghiệp manh mún. Tính năng 
động của nền kinh tế hạn chế. Điều kiện kinh tế, xã hội đó hình thành thế giới quan và nhân sinh quan ở các nhà tư tưởng có sự đan xen giữa yếu tố duy vật và duy tâm, biện chứng và siêu hình. Tuy nhiên, khi đánh giá, xem xét sự vật, hiện tượng, cha ông ta đã sớm có cách nhìn biện chứng, mặc dù còn chất phác, cảm tính về nguồn gốc và bản tính con người. Vào thời kỳ Bắc thuộc, ảnh hưởng nhân sinh quan của Phật giáo khi truyền vào Việt Nam, Thiền sư Mâu Tử cho rằng, nguồn gốc con người "vốn tự vô sinh. Nguyên khí mạnh là đất., nhuyễn là nước, nóng là lửa, động là gió, bốn thứ hòa hợp, thần thức sinh ra, nếu dừng dục trống lòng thì thần thức chốn về không" [2, p. 165]. Ông quan niệm, chết chưa phải là đã hết, chỉ có thân thể rữa nát còn thần hồn vẫn bất diệt. Phát triển tư tưởng Phật giáo, thiền phái Tì $\mathrm{Ni}$ Đa Lưu Chi, thời kỳ nhà Lý, thiền phái đầu tiên ở Việt Nam tại chùa Pháp Vân, quan niệm mỗi cá nhân xuất hiện là do "nghiệp lực, nghiệp duyên" [2, p. 239]. Con người có nghiệp là do vô minh, không nhận ra được thế giới này là vô thường. Cuộc đời con người là phù du, luôn biến đổi vô thường. Kế thừa quan điểm của thiền phái Tì Ni Đa Lưu Chi, Trần Thái Tông (1212-1277) cho rằng, bản nguyên của vũ trụ, vạn vật và con người đều sinh ra từ "cái tâm (không, hư" mà ra" [2, p. 306]. Trần Thái Tông nhận thức về thế giới vạn vật và con người hướng vào tâm, xuất phát từ cái tâm.

Từ thế kỷ thứ $X$, bên cạnh sự phát triển của Phật giáo, Nho giáo và Đạo giáo đã từng bước khẳng định được vị thế của mình trong đời sống xã hội Việt Nam. Đến đầu thế kỷ XV, Nho giáo chiếm ưu thế trong sinh hoạt chính trị, xã hội ở nước ta. Theo đó, con người được quan niệm là được sinh ra từ trời đất, là bộ phận tinh túy nhất của tự nhiên. Danh y nổi tiếng thời Trần, Nguyễn Bá Tính cho rằng: "Tam tài là trời, đất, người. Con người chịu được chỉnh khí của trời đất, tinh khôn hơn vạn vật" [3, p. 498]. Còn Nguyễn Trãi quan niệm, con người là sản phẩm của quá trình vận động của trời đất. Ông viết: Trời đất đối với muôn vật, tuy có lúc nổi giận sấm sét, song cái ý hiếu sinh vẫn thể hiện bên trong” [4, p. 796]. Sau này, Nguyễn Bỉnh Khiêm khái quát nguồn gốc con người bằng thơ: "Thái cực từ khi mới phân chia đã phân định rõ vị trí của tam tài. Trong và nhẹ bay lên trên làm trời, nặng và đục lắng xuống làm đất, ở giữa kết tụ lại thành người. Bẩm thụ cùng một khí" (Cảm hứng). Con người, vạn vật có quan hệ hữu cơ với với nhau và gắn bó chặt chẽ với các bộ phận của giới tự nhiên và đều do trời sinh ra, trời nuôi dưỡng. Tiếp tục quan điểm con người được sinh ra từ trời đất, Ngô Thì Nhậm viết: "Khi khí âm dương đọng lại, tạo ra muôn loài, sinh ra từ chỗ "thức tỉnh", vậy thì thức tỉnh chính là thái cực sinh ra lưỡng nghi vậy" [5, p. 158]. Lê Quý Đôn cũng thường đề cập đến mối quan hệ thống nhất giữa trời và con người trong tác phẩm của mình: "Người ta cùng với trời đất là một gốc; suốt ngày động tác ăn uống, càng cùng với khí đất cùng chung đụng" (Vân đài loại ngữ) $[6, p .45]$. Ông đã quy con người và tự nhiên về một mối và gắn tất cả trong mối quan hệ với trời. Nguyễn Trường Tộ (1830-1871) được xem là người Việt Nam đầu tiên tiếp thu kiến thức mới Tây Âu, thời vua Tự Đức, xuất phát từ quan điểm "trời” là nhân tố sinh ra vạn vật và quyết định vận mệnh của con người. Ông viết: "Tạo vật sinh ra muôn vật để con người sử dụng mà không tiếc một thứ gì", "tạo vật sinh ra loài người đều do cùng một nguồn gốc như nhau cả" [7, p. 155]. Quan điểm về nguồn gốc con người là sự kết tinh của trời và đất được phát triển đến đầu thế kỷ $\mathrm{XX}$ khi Phan Bội Châu cho rằng, con người là sự kết hợp giữa trời và đất, tuy nhiên sự kết hợp này không giống nhau ở mỗi người vì thế mới có giới tính và nét đẹp khác nhau. Ông viết: "Càn là cha, khôn là mẹ, người hỗn hợp với càn khôn mà ở chính giữa" [8, p. 182]. Ông phủ nhận con người là sản phẩm của thần thánh, Thượng đế tạo nên. Quan điểm về nguồn gốc của con người được thay đổi căn bản trong lịch sử tư tưởng đến đầu thế kỷ $\mathrm{XX}$, với sự xuất hiện của nhà tư tưởng Nguyễn An Ninh (1860-1931). Nghiên cứu và kế thừa phép biện chứng duy vật của chủ nghĩa Mác, ông phủ nhận quan điểm duy tâm, tôn giáo về nguồn gốc của con người. Ông cho rằng, con người có nguồn gốc tiến hóa từ tự nhiên, không có linh hồn bất tử, thể xác có gen di truyền từ thế hệ trước. Ông viết: "Khoa học kinh nghiệm nói cái trứng (ovule) của đờn bà và con tinh trùng (spermatozoide) của đàn ông hiệp nhau lại hóa ra một tế bào. Cái tế bào này là căn gốc sanh lần lần ra đủ cả tế bào mà làm cả cái xác thịt. Cái tánh chất của nó do nơi tánh chất của cái trứng và của con tinh trùng" [9, p. 1212].

Vấn đề tính người được các nhà tư tưởng trong lịch sử quan tâm, luận giải. Các nhà tư tưởng cho rằng, bản tính con người là thiện, do trời đất phú cho. Theo Nguyễn Bỉnh Khiêm, tính người là do thiên tính, tính thiện của con người có sẵn do trời đất sinh ra. Tính người không phải là bất biến, mà luôn thay đổi, phụ thuộc vào sự thay đổi của hoàn cảnh, điều kiện sống. Con người vốn tính thiện. Ngô Thì Nhậm cũng cho rằng, con người khi sinh ra vốn mang tính thiện nhưng do hoàn cảnh sống mà tâm tính con người bị thay đổi, trở nên bạc ác. Ông viết: "Ôi! Phàm đã làm người, ai chẳng muốn làm điều tốt, chỉ vì hoàn cảnh bắt buộc mới làm việc ác, để cho lương tâm mòn mỏi”. Ông nhận thẩy rằng, do "tụ lập bè đảng, lấy việc cưỡng 
bức để sinh nhai cũng là chỗ bất đắc dĩ, hoặc vì đói rét mà bức bách, hoặc vì bạo ngược xua đuổi, mới đến nương thân nơi sóng gió, không có lối thoát ra" [10, p. 91]. Ông đề cao vai trò của giáo dục trong việc thay đổi bản tính con người: "Người ta, mặt không giống nhau thì lòng cũng không giống nhau (...). Vậy thì ở chỗ không giống nhau đó, đem đạo lý bàn bạc với nhau để làm cho giống nhau, ở chỗ không thường tụ họp đó, ta lấy đức tính tốt khuyên bảo nhau để thường tụ họp; thờ thần minh không lỗi đạo thành kính, thờ vua cha không lỗi đạo trung hiếu, ở gia đình thì làm người lương thiện, ở làng xóm thì làm người nết na; thẳng thắn nhưng không tranh giành nhau, hòa nhã để cư xử với nhau. Khiến cho văn vật đời đời sáng láng, khoa mục ngày càng hưng thịnh" [11, p. 179]. Đến Nguyễn Trường Tộ, ông quan niệm rằng, đạo đức là bản tính con người, tuy nhiên, do hám cái lợi và u mê nên làm cho trí não bị hôn mê, nên con người quên mất nhân nghĩa, do vậy con người cần phải học nâng cao kiến thức để phục vụ cho đất nước. Phan Bội Châu cho rằng, bản tính vốn có của con người là biết yêu thương nhau: "Cùng một chủng tộc mà hại lẫn nhau, đó là giống vật tầm thường. Cùng chủng tộc biết yêu thương nhau mới gọi là con người” [8, p. 346]. Từ quan điểm này, ông kêu gọi mọi người dân trên đất nước Việt Nam phải đoàn kết, yêu thương lẫn nhau để giải phóng dân tộc.

Có thể thấy rằng, vấn đề về nguồn gốc và bản tính con người trong lịch sử tư tưởng Việt Nam ảnh hưởng mạnh mẽ bởi thế giới quan và nhân sinh quan Phật giáo và Nho giáo, tư tưởng truyền thống khẳng định con người là sản phẩm tinh túy của trời, đất, mang bản tính thiện. Các nhà tư tưởng thể hiện tư duy biện chứng khi cho rằng, nguồn gốc con người có mối quan hệ chặt chẽ với tự nhiên, và bản tính con người thay đồi dựa trên sự thay đổi của hoàn cảnh môi trường sống. Do vậy, các nhà tư tưởng đề cao vai trò của giáo dục trong việc con người hướng thiện, yêu thương lẫn nhau để xây dựng và phát triển đất nước.

\section{Về vị trí và vai trò của con người}

Trong lịch sử tư tưởng Việt Nam, vấn đề về vị trí, vai trò của con người được đề cập, chủ yếu là nhấn mạnh đến vị trí và vai trò của Nhân dân. Các nhà tư tưởng đánh giá cao vai trò của Nhân dân trọng sự nghiệp dựng nước và giữ nước. Coi Nhân dân là lực lượng quyết định đến sự nghiệp bảo vệ Tổ quốc, quan tâm đến đời sống và nguyện vọng của Nhân dân được xem là việc hàng đầu của đạo trị nước. Trần Quốc Tuấn chủ trương dựa vào dân để đánh giặc. Ông nhấn mạnh đến việc "khoan thư sức dân để làm kế sâu gốc bền rễ đó là thượng sách để giữ nước" [12, pp. 88-89]. Vua Lý Cao Tông xem Nhân dân là chỗ dựa: "Dân đã oán thì trẫm còn dựa vào ai? Nay trẫm dễ sửa lỗi cùng dân đổi mới” [13, p. 301]. Dân chúng là người dân lao động chịu nhiều đau khổ nhất của nạn áp bức, bóc lột của giặc ngoại xâm, Nguyễn Trãi viết: "Thui dân đen trên lò bạo ngược, hãm con đỏ dưới hố tai ương" [14, p. 77]. Vậy nên, an dân, thương dân chính là điều kiện để ổn định xã hội, để đánh thắng giặc ngoại xâm. Sử thần triều Lê đánh giá về Lý Thánh Tông: "Vua khéo kế thừa, thực lòng thương dân, trọng việc làm ruộng, thương kẻ bị hình, vỗ về người xa, yên ủi người gần... đáng là bậc vua tốt" [13, p. 283].

Các nhà tư tưởng đều nhấn mạnh đến vai trò của Nhân dân trong sự nghiệp đánh đuổi giặc ngoại xâm và phát triển kinh tế, xã hội. Sức mạnh của Nhân dân được nhấn mạnh như: "Nước lấy dân làm gốc" "Dân có sức mạnh như nước, đẩy thuyền là dân, lật thuyền cũng là dân". Tuy nhiên, bên cạnh những giá trị tư tưởng tích cực về sức mạnh của dân, các nhà tư tưởng trong lịch sử có một số hạn chế nhất định về vai trò của con người như coi dân là lực lượng đáng thương xót, là "con đỏ", là "dân đen", "lưu dân", "loạn dân",...

Có thể thấy rằng, việc nhận thức, đánh giá cao vai trò của Nhân dân không chỉ là yêu cầu của cuộc kháng chiến chống xâm lược của ngoại bang mà còn là sự khái quát, tổng kết những kinh nghiệm của lịch sử trong dòng chảy của chủ nghĩa yêu nước, kết tinh của quan niệm sống, lối sống trong truyền thống dân tộc Việt Nam.

\section{Tư tưởng về ý thức chủ quyền dân tộc, lòng tự hào dân tộc}

Ý thức về cộng đồng người Việt và chủ quyền đất nước được hình thành và phát triển từ trước thời kỳ Bắc thuộc. Ban đầu những tư tưởng này còn biểu hiện đơn giản. Dưới sự thống trị của ngoại bang, ý thức về cội nguồn, về cộng đồng dân tộc, chủ quyền quốc gia đã mang nhiều yếu tố lý tính và đã hình thành hệ thống các quan niệm. Câu chuyện Âu Cơ lấy Lạc Long Quân, sinh ra một bọc trăm trứng, nở ra một trăm người con, năm mươi người con theo cha xuống biển, năm mươi người con theo mẹ lên núi,... là ý thức về cộng đồng được sự tích hóa. Trong bài "Nam quốc sơn hà" của Lý Thường Kiệt, nhận thức của Nhân dân về độc lập, chủ quyền và lãnh thổ của Nhân dân được công bố một cách rõ ràng "Sông núi nước Nam, vua Nam ở/Rành rành định phận tại sách Trời/Cớ sao lũ giặc sang xâm phạm/Chúng bay sẽ bị đánh tơi bời” [15, $\mathrm{p}$. 391]. Lời tuyên bố của Lý Thường Kiệt là một sự khẳng định ý chí của Nhân dân ta quyết tâm bảo vệ độc 
lập chủ quyền của đất nước, là niềm tin vô hạn của Nhân dân trong sự nghiệp giữ nước. Ý chí, quyết tâm đánh đuổi quân thù được truyền đến cho tất cả mọi người trong bài Hịch tướng sĩ của Trần Quốc Tuấn: "Ta thường tới bữa quên ăn, nửa đêm vỗ gối, ruột đau như cắt, nước mắt đầm đìa; chỉ căm tức chưa xẻ thịt lột da nuốt gan uống máu quân thù” [16, p. 391]. Chính lòng tự hào dân tộc đã tạo nên những chiến công hiển hách trước quân Tống, quân Nguyên. Đỉnh cao của quan niệm về dân tộc, ý thức độc lập dân tộc và lòng tự hào dân tộc dưới thời kỳ phong kiến là lý luận của Nguyễn Trãi. Trong tác phẩm Đại cáo bình Ngô, Nguyễn Trãi đã khẳng định dân tộc Việt Nam hội đủ các yếu tố về: văn hiến, lãnh thổ, phong tục tập quán, lịch sử, anh hùng hào kiệt-sánh ngang hàng với các dân tộc phương Bắc:

"Xét như nước Đại Việt ta,

Thật là một nước văn hiến.

Bờ cõi sông núi đã riêng,

Phong tục Bắc Nam cũng khác.

Trải Triệu, Định, Lý, Trần nối đời dựng nước,

Cùng Hán, Đường, Tống, Nguyên đều chủ một phương.

Tuy mạnh yếu có lúc khác nhau,

Mà hào kiệt không bao giờ thiếu" [14, p. 77].

Từ nhận thức về dân tộc, Nguyễn Trãi khẳng định trong Đạo cáo bình $N g o ̂$ về tư tưởng độc lập dân tộc. Dân tộc Việt Nam sẵn sàng không quản hy sinh để bảo vệ nền độc lập tự do của mình. Đây là truyền thống đấu tranh bất khuất của dân tộc và được phản ánh đậm nét qua các nhà tư tưởng trong lịch sử tư tưởng Việt Nam.

Ý thức chủ quyền và lòng tự hào dân tộc được hình thành ngày từ những ngày đầu dựng nước và giữ nước. Tinh thần này là sợi chỉ đỏ xuyên suốt lịch sử phát triển của dân tộc, là niềm tự hào và sức mạnh của các thế hệ Việt Nam đánh đuổi các thế lực xâm lược hùng mạnh trên thế giới

\section{Tư tưởng về đạo làm người}

Nội dung về vấn đề con người được các nhà tư tưởng trong lịch sử Việt Nam đặc biệt quan tâm là vấn đề đạo làm người. Con người cá nhân tồn tại ràng buộc trong các mối quan hệ với cộng đồng xã hội, gắn với những bước thăng trầm của vận mệnh dân tộc. Do vậy, những nguyên tắc, những chuẩn mực của đạo làm người được hình thành, làm cơ sở để đối nhân xử thế, để xác định phương thức hành động cho con người và như vậy nó phản ánh được yêu cầu của lịch sử là tất yếu. Trong thời kỳ Bắc thuộc, quan điểm nhân sinh, quan điểm về đạo làm người, thể hiện trước hết ở sự tôn kính và biết ơn cha mẹ, tồ tiên; sự tôn kính và nghe theo thủ lĩnh. Cùng với quá trình giao lưu về mặt vắn hóa với các dân tộc khác, quan niệm về đạo làm người của các nhà tư tưởng Việt Nam chịu ảnh hưởng rõ rệt bởi đạo: Nho, Phật và Lão - Trang, trong đó Nho giáo có ảnh hưởng mạnh mẽ nhất. Các nhà tư tưởng, nhà yêu nước Việt Nam đã khai thác Nho giáo để diễn đạt các nội dung yêu nước, yêu dân, tin ở năng lực con người, thái độ của con người trước vận mệnh dân tộc. Các nhà tư tưởng yêu nước thời Lý - Trần, nhấn mạnh khái niệm trung nghĩa, coi trung nghĩa là một yêu cầu quan trọng trong cuộc kháng chiến chống giặc ngoại xâm. Trần Quốc Tuẩn đã lấy những tấm gương trung nghĩa của lịch sử Trung Quốc để giáo dục tướng sĩ: "Ta thường nghe: Kỷ Tín đem mình chết thay, cứu thoát cho Cao Đế; Do Vu chìa lưng chịu giáo che chở cho Chiêu Vương... Từ xưa các bậc trung thần nghĩa sĩ bỏ mình vì nước đời nào chả có" [16, p. 390]. Đối với quân thù, cần có thái độ kiên quyết, rõ ràng: "Giặc Mông Thát với ta là kẻ thù không đội trời chung, mà các người cứ điềm nhiên không muốn rửa nhục, không lo trừ hung, lại không dạy quân sĩ, chẳng khác nào quay mũi giáo mà xin đầu hàng, giơ tay không mà chịu thua giặc" [16, p. 392]. Theo Nguyễn Trãi, thái độ của người yêu nước trước hết là phải cứu nước, cứu dân: "Việc nhân nghĩa cốt ở yên dân" [14, p. 77]. Nguyễn Trãi chú trọng đến mối quan hệ vua tôi, bạn bè và nhấn mạnh các đức tính: nhân, trí, dũng. Nguyễn Bỉnh Khiêm có chủ trương con người phải sống theo những nguyền tắc đạo đức của Nho giáo, phải thực hiện "cương thường". Các quan niệm về con người luôn luôn được gắn với những nội dung cụ thề như vấn đề vị trí, vai trò của con người với tư cách là động lực của cuộc đấu tranh giữ nước; đạo đức của con người gắn liền với đường lối và phương châm trị nước; những vấn đề đạo lý của con người gắn liền với ý thức trách nhiệm, thái độ của con người trước vận mệnh của đất nước,... Các quan điểm về con người luôn có sự gắn bó, không tách rời các quan điểm về dân tộc và quốc gia có chủ quyền và các vấn đề phương pháp luận của công cuộc xây dựng và bảo vệ đất nước. Tư tưởng chung về con người đã có sự phát triển thành một hệ thống và có bản sắc riêng, đáp ứng được yêu cầu của công cuộc dựng nước và giữ nước trong cả một quá trình lịch sử lâu dài. Khí phách con người Việt Nam, tư tưởng yêu nước của dân tộc được thể hiện qua nhiều áng 
văn thơ bất hủ, đanh thép như Hịch tuoóng sĩ của Trần Hưng Đạo: "Ta thường tới bữa quên ăn, nửa đêm vỗ gối, ruột đau như cắt, nước mắt đầm đìa; chỉ giận chưa thể xả thịt, lột da, ăn gan uống máu quân thù; dẫu cho trăm thân ta phơi ngoài nội cỏ, nghìn thây ta bọc trong da ngựa, cũng nguyện xin làm" [16, p. 391]. Tỉnh thần đấu tranh kiên cường, bất khuất dựa trên nền tảng và thế mạnh của chính nghĩa được Nguyễn Trãi nhấn mạnh trong tác phẩm Bình Ngô đại cáo: "Nghĩ thế thù khôn há đội trời chung. Thề giặc nước khó cùng chung sống" [14, p. 78]. Tự tin ở mình, tin ở con người, ở sức mạnh của dân tộc, không trông đợi ở trời phật hay ở bất kỳ một "đấng cứu thế" nào trong chiến tranh giải phóng, đó là một đặc điểm nổi bật của con người Việt Nam.

Lòng thương người, khoan dung độ lượng với những kẻ lầm đường lạc lối được các nhà tư tưởng đề cao trong quan điểm về đạo làm người. Lối sống tương thân tương ái, sống có đạo lý, nhân nghĩa; khi gặp hoạn nạn thì đồng cam cộng khổ, cả nước một lòng; tính thích nghi và hội nhập; iối ứng xử mềm mỏng và truyền thống hiếu học, trọng nghĩa, khoan dung cũng được thể hiện rõ nét qua các câu ca dao, tục ngữ như: "Bầu ơi thương lấy bí cùng - Tuy rằng khác giống nhưng chung một giàn"; "Nhiễu điều phủ lấy giá gương Người trong một nước thì thương nhau cùng"; "Lá lành đùm lá rách"; "Uống nước nhớ nguồn”;... Như vậy, do những đặc điểm về kinh tế, chính trị, xã hội trong lịch sử Việt Nam, nên các nhà tư tưởng ít quan tâm đến những vấn đề "bản chất con người", "mối quan hệ giữa linh hồn và thể xác",... mà quan tâm đến những quan niệm về chuẩn mực đạo đức và đạo làm người, giáo dục con người, cách đối nhân xử thế, vai trò, vị trí của con người đối với cộng đồng, đất nước, ,... Chính những tư tưởng này đã phản ánh sâu sắc cuộc sống lao động gian khổ của Nhân dân, sự gắn bó giữa con người với thiên nhiên, giữa con người với nhau trong mối quan hệ gia đình, láng giềng, dòng họ của người Việt cũng như trong cộng đồng nhà - làng - nước dân tộc và đặc biệt là phản ánh cuộc kháng chiến trường kỳ vô cùng gian khổ của Nhân dân chống lại các thế lực ngoại xâm.

\section{KẾT LUẬN}

Thông qua những nội dung cơ bản về vấn đề con người trong lịch sử tư tưởng Việt Nam, chúng ta thấy được một số đặc điểm nổi bật đó là: con người luôn được xem là sản phẩm tinh túy của trời đất, là trung tâm của vũ trụ; xem xét con người trong mối quan hệ với lợi ích và vận mệnh dân tộc, luôn đặt lợi ích dân tộc lên trên hết; đề cao tính cộng đồng, nhân nghĩa và khoan dung. Nội dung co bản, xuyên suốt trong các vấn đề về con người trong lịch sử là tư tướng yêu nước. Có thể nói, tư tưởng yêu nước là "giá trị đứng đầu bảng giá trị tinh thần của dân tộc Việt Nam" [17, p. 15]. Bởi "Lịch sử Việt Nam, dài nhiều nghìn năm, chủ yếu là lịch sử đấu tranh giành lại và bảo vệ độc lập dân tộc (...) Sự hình thành tư tưởng yêu nước đi đôi với sự hình thành và phát triển của quốc gia dân tộc $(. .$.$) là kim chỉ nam cho hành động, là một tiêu chuẩn để$ nhận định đúng - sai; tốt - xấu" [18, p. 78]. Tư tưởng yêu nước hình thành và phát triển gắn liền với cuộc đấu tranh của cộng đồng dân tộc Việt Nam chống lại sự bành trướng xâm lược của phong kiến phương Bắc và các thế lực ngoại xâm khác. Tư tưởng yêu nước trước hết thể hiện ở ý thức về dân tộc, về dân tộc độc lập và lòng tự hào dân tộc. Trên cơ sở đó, các nhà tư tưởng luôn ý thức suy nghĩ để tìm con đường, giải pháp, động lực để cứu nước, cứu dân nhằm giành chủ quyền lâu dài cho dân tộc.

Vấn đề về con người trong lịch sử tư tưởng Việt Nam luôn được gắn với vận mệnh dân tộc, gắn với quá trình dưng nước và giữ nuớc của Nhân dân. Mặc dù chịu ảnh hưởng chi phối của Nho giáo, Phật giáo, Đạo giáo nhưng các nhà tư tưởng Việt Nam trong lịch sử không áp dụng dập khuôn, máy móc mà có sự vận dụng phù hợp với điều kiện cụ thể của dân tộc. Các quan điểm về con người thời kỳ này chỉ hạn hẹp trong phạm vi ý thức hệ phong kiến với khuynh hướng chủ yếu là chủ nghĩa duy tâm. Tuy nhiên, có thể khẳng định rằng, những vân đề cơ bản về con người trong lịch sử tư tưởng Việt Nam, phản ánh sâu sắc những điều kiện về kinh tế, chính trị, xã hội; phản ánh những giá trị bền vững, những tinh hoa của dân tộc Việt Nam được vun đắp nên qua lịch sử hàng ngàn năm đấu tranh dựng nước và giữ nước là: "lòng yêu nước nồng nàn, ý chí tự cường dân tộc, tinh thần đoàn kết, ý thức cộng đồng gắn kết cá nhân - gia đình - làng xã - Tổ quốc; lòng nhân ái, khoan dung, trọng nghĩa tình, đạo lý; đức tính cần cù, sáng tạo trong lao động; sự tinh tế trong ứng xử, tính giản dị trong lối sổng,..." $[19$, p. 56].

Sinh thời, Chủ tịch Hồ Chí Minh căn dặn: "Muốn xây dựng chủ nghĩa xã hội, trước hết cần có những con người xã hội chủ nghĩa" $[20$, p. 66]. Ngày nay, vấn đề xây dựng con người Việt Nam đáp ứng yêu cầu của công cuộc xây dựng công nghiệp hóa, hiện đại hóa đất nước càng trở nên cấp thiết. Chính vì vậy, Đảng Cộng sản Việt Nam luôn xác định nhất quán "Xây dựng con người Việt Nam phát triển toàn diện phải trở thành một mục tiêu của chiến lược phát triển" [1, p. 126]. Phát triển con người Việt Nam phát triển toàn diện trên cơ sở "Đúc kết và xây dựng hệ giá trị văn hóa và hệ giá trị chuẩn mực của con người Việt Nam 
thời kỳ công nghiệp hóa, hiện đại hóa và hội nhập quốc tế” [1, pp. 126-127]. Trong đó, nội dung trọng tâm xây dựng con người Việt Nam hiện đại được xác định là "bồi dưỡng tinh thần yêu nước, lòng tự hào dân tộc, đạo đức, lối sống và nhân cách. Tạo chuyển biến mạnh mẽ về nhận thức, ý thức tôn trọng pháp luật, mọi người Việt Nam đều hiểu biết sâu sắc, tự hào, tôn vinh lịch sử, văn hóa dân tộc" [21,p. 49]. Ngày nay, Việt Nam đang trong quá trình đẩy mạnh công nghiệp hóa, hiện đại hóa, hội nhập quốc tế sâu rộng và toàn diện trên tất cả các lĩnh vực kinh tế, chính trị, văn hóa, xã hội. Để đất nước hội nhập mà không hòa tan, không đánh mất bản sắc dân tộc, việc kế thừa, phát huy những đặc điểm cơ bản vấn đề con người trong lịch sử tư tưởng có ý nghĩa đặc biệt quan trọng, hình thành các thế hệ công dân giàu lòng yêu nước, có ý thức làm chủ, trách nhiệm công dân, ý thức công đồng, sống có văn hóa, có tình nghĩa, góp phần giữ vững văn hóa truyền thống đậm đà bản sắc dân tộc, trở thành sức mạnh nội sinh thúc đầy đất nước phát triển.

\section{TÀI LIẸU THAM KHẢO}

1] . C. s. V. Nam, Văn kiện Đại hội đại biểu toàn quốc lần thư XII, Hà Nội: Văn phòng Trung ương Đảng, 2016.

[2] D. Chính, Lịch sư tư tuơơng triết học Việt Nam tù thời kỳ dựng nước đến đầu thế kỷ XX, Hà Nội: Nxb. Chính trị Quốc gia, 2013.

[3] N. B. Tĩnh, Tuệ Tĩnh (toàn tập), Tp. Hồ Chí Minh: Hội y học cổ truyền, 1994.

[4] T. t. n. c. Q. học, Nguyễn Trãi, Toàn tập (tân biên), tập 1, Hà Nội: Nxb. Văn học, 2001.

[5] V. n. c. H. Nôm, Ngô Thì Nhậm, toàn tập, tập V, Hà Nội: Nxb Khoa học xã hội, 2006.

[6] V. K. h. x. h. V. Nam, Đại Việt sử ký toàn thu, tập 2, Hà Nội: Nxb Khoa học xã hội, 1998.

[7] T. B. Cần, Nguyễn Truoơng Tộ - Con ngưòi và Di thảo, TP. Hồ Chí Minh: Nxb. Thành phố Hồ Chí Minh, 2002.

[8] P. B. Châu, Toàn tập, tập 4, Huế: Nxb. Thuận Hóa, 1990.

[9] Mai Quốc Lên - Nguyễn Sơn, Nguyễn An Ninh tác phẩm, Hà Nội: Nxb. Văn học, 2009.

[10] T. t. k. h. x. h. v. n. v. q. gia, Tổng tập văn học Việt Nam, tập. 9A, Hà Nội: Nxb Khoa học xã hội, 1993.

[11] T. t. k. h. x. h. v. n. văn, Tuyển tập tho văn Ngô Thì Nhậm, Quyển II, Hà Nội: Nxb Khoa học xã hội, 1978.

[12] S. g. t. Lê, Đại Việt sử ký toàn thur. Tập 2, Hà Nội: Khoa học xã hội, 1967.

[13] S. g. t. Lê, Đại Việt sủ ký toàn thu. Tập 1, Hà Nội: Khoa học xã hội, 1967.

[14] V. S. học, Nguyễn Trãi toàn tập, Hà Nội: Khoa học xã hội, 1976.

[15] V. V. học, Tho văn Lý - Trần, tập 1, Hà Nội: Khoa học xã hội, 1977.

[16] V. V. học, Tho văn Lý - Trần, tập 2, quyển thuợng, Hà Nội: Khoa học xã hội, 1989.

[17] T. V. Giàu, Trong dòng chủ luu của văn học Việt Nam: Tu tuởng yêu nuớc, TP.HCM: Nxb Văn nghệ, 1983.

[18] T. V. Giàu, Bản lĩnh Việt Nam, TP.HCM: Nxb Trẻ, 2005.

[19] Đ. C. s. V. Nam, Văn kiện Hội nghị lần thứ năm Ban chấp hành Trung uoong khóa VIII, Hà Nội: Chính trị Quốc gia, 1998.

[20] H. C. Minh, Toàn tập, tập 13, Hà Nội: Nxb. Chính trị Quốc gia - Sự thật, 2011.

[21] Đ. C. s. V. Nam, Văn kiện hội nghị lần thứ 9 Ban Chấp hành trung uoong khóa XI, Hà Nội: Nxb. Chính trị Quốc gia - Sự thật, 2014.

Ngày nhận bài:31/08/2020

Ngày chấp nhận đăng:12/11/2020 